GEOLOGICAL SURVEY CIRCULAR 825

\title{
Hydrates of Natural Gas: A Review of Their Geologic Occurrence
}



Hydrates of Natural Gas:

A Review of Their Geologic Occurrence

By Keith A. Kvenvolden and Mark A. McMenamin

$\begin{array}{llll}\text { GEOLOGICAL SURVEY CIRCULAR } & 825\end{array}$ 


\section{United States Department of the Interior}

\section{CECIL D. ANDRUS, Secretary}

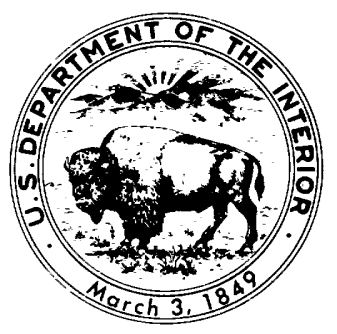

\section{Geological Survey}

H. William Menard, Director 


\section{CONTENTS}

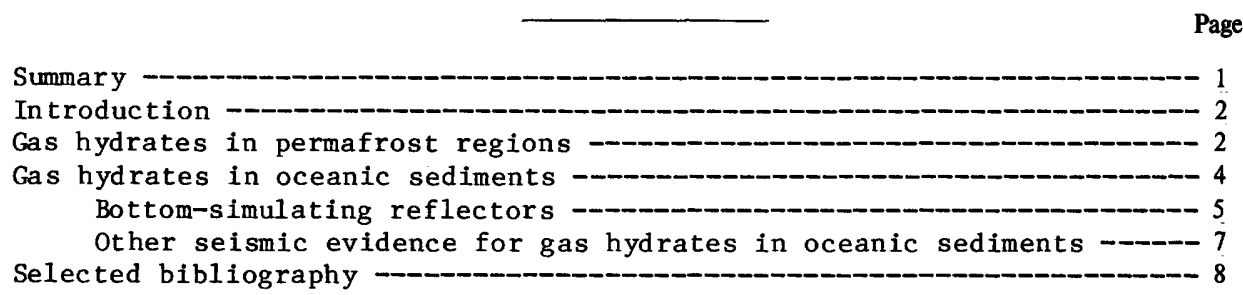

\section{ILLUSTRATIONS}

Figure 1. Phase boundary diagram showing free methane gas and methane hyd rate -

2. Map showing location of known and inferred occurrences of gas hydrates in permafrost regions and in oceanic sediment -- 3

3. Graph of gas hydrate zone shown as intersection of geothermal gradient with hydrate-gas phase boundary -

4. Diagram showing idealized section of methane gas hydrate zone in sediments of outer continental margins -

5. Diagrammatic seismic profile of Blake-Bahama Outer Ridge showing bottom-simulating reflector - 6

\section{TABLES}

Table 1. Geologic, geophysical, and geochemical evidence for gas hydrates beneath permafrost - 3

2. Geologic, geophysical, and geochemical evidence for gas hydrates in the seafloor 


\section{.}




\title{
Hydrates of Natural Gas:
}

\section{A Review of Their Geologic Occurrence}

\author{
By Keith A. Kvenvolden and Mark A. McMenamin'
}

\section{SUMMARY}

Gas hydrates are a type of inclusion compound or clathrate formed as icelike mixtures of gas and water in which gas molecules are trapped within a framework or cage of water molecules. Large quantities of natural gas (mainly methane) can be trapped in sediments in the form of gas hydrates. The pressure and temperature conditions for the formation of gas hydrates are found in regions of permafrost and beneath the sea in outer continental margins and ocean basins. In addition to suitable temperature and pressure conditions, sufficient concentrations of methane must be present for hydrate stability. This methane may be produced in sediments by biological processes; however, the extent of this production is not fully understood. Methane could also migrate from thermochemically altered organic matter at depth.

The presence of gas hydrates in permafrost regions has been established at the Messoyakha gas field in western Siberia, in two exploratory wells in the Mackenzie Delta area of Canada, and in a wildcat well on the North Slope of Alaska. In the Alaskan we11, a pressure core barrel successfully recovered gas hydrate in sediment at in situ temperature and pressure. Although gas hydrates have now been identified in permafrost areas, the geographical extent of these hydrates has not yet been determined.

Geologic, geochemical, and geophysical evidence suggests that gas hydrates can exist in many areas beneath the seafloor. Geologic evidence consists of (1) widespread areas where pressures and temperatures are suitable for gashydrate stability and (2) recovery of deep-sea sediment cores that release gas and cool endothermically when exposed to sea-level temperature and pressure. Geochemical observations include (1) high concentrations of methane in sediment,

'Present address: Department of Geological Sciences, University of California, Santa Barbara, CA 93106 usually accompanied by low concentrations of ethane, and (2) gas released from thawing cores in the volumes expected for the decomposition of gas hydrate. Geophysical evidence includes (1) seismic anomalies that can be explained by the properties of sediments containing hydrates, (2) high acoustic velocity in sediments from suspected hydrate zones, and (3) laboratory experiments which show that the acoustic velocities of sediment increase when gas hydrate is formed in the sediment.

The main seismic evidence for subnarine gas hydrates are reflectors that simulate the topography of the seafloor. Such reflectors appear on seismic records from the east coast of North America, the North Pacific, the Bering Sea, and the Pacific and Atlantic coasts of Central America. They lie anywhere from 100 to 1,100 meters below the bottom. Bottom-simulating reflectors have been seen only in water deeper thon $400 \mathrm{~m}$ and are generally manifest on seismic records as a reflection polarity reversal caused $\mathrm{ky}$ an abrupt decrease in seismic velocity. The exact relations of bottom-simulating reflectors to gas hydrate zones are uncertain. The change in seismic impedance may mark the bottom of the gashydrate zone where free methane gas is trapped beneath the hydrate 1ayer. Other features on seismic records that may indicate the presence of hydrates are bottom-paralleling bright spots, pagoda structures, and deep-water velocity amplitude features (VAMP's).

Not all bottom-simulating reflectors may be directly related to gas hydrates. For example, a bottom-simulating reflector lacking polexity reversal in sediments of the Bering Sea is currently thought to represent a migrating diagenetic boundary related to the dissolution of diatoms and the induration of claystone.

If large quantities of gas hydrate are widespread in permafrost regions and in offshore marine sediments, they may be potential energy resources. The gas within the hydrate itself may 
not be recoverable, but the free gas trapped beneath it may be the important resource.

\section{INTRODUCTION}

Gas hydrates are a special kind of clathrate formed from a mixture of natural gas and water. $\mathrm{Clathrates}$ are inclusion compounds in which two or more chemical compounds form a stable crystalline mixture. One constituent forms the clathrate framework, a molecular lattice with an ordered geometric pattern. The other constituents of the clathrate fill the sites or cages within the framework structure. A clathrate framework, because it may contain many vacant sites, is a nonstoichiometric substance (a substance that cannot be accurately described by a single chemical formula). Water, because of its hydrogenbonding properties, is an excellent clathrate framework compound. An expanded ice lattice forms cages that can contain gas molecules such as argon, methane, propane, isobutane, sulfur dioxide, carbon dioxide, and hydrogen sulfide.

The term "gas hydrate" is used here to mean a water-methane clathrate that may or may not contain ethane, propane, and other hydrocarbons. Under suitable pressures, natural gas, which contains mainly methane, can interact with water to form a solid icelike mixture, that is, a gas hydrate, at temperatures considerably above the freezing point of water (fig. 1). The amount of methane needed for hydrate formation depends on temperature and pressure. In the methane-water system, only methane present in excess of the amount soluble in water is available for hydrate formation. In an ideally saturated hydrate, with all cages filled by methane molecules, the molar ratio of methane to water can be nearly $1: 6$. The formula for an ideal stoichiometric methane-water clathrate is $\mathrm{CH}_{4} \cdot 5-3 / 4 \mathrm{H}_{2} \mathrm{O}$. One cubic meter of this ideal hydrate would contain the equivalent of about 170 cubic meters of free methane gas. Gas hydrates found in nature contain less gas than this because the lattice cages are not completely filled. Nevertheless, gas hydrates in reservoir rocks can contain much more methane per unit volume than could be contained as free gas in the same space. This fact suggests that if gas hydrates exist in large quantities in the upper few hundred meters of the earth's crust, they would constitute a significant potential energy resource. Also, because gas hydrates are impermeable to free gas, a layer of hydrate could trap economically important quantities of free gas below it.

Petroleum exploration drilling in Arctic regions has established the occurrence of gas hydrate below permafrost (fig. 2). Marine seismic studies and Deep Sea Drilling Project cores strongly indicate the presence of gas hydrates in some seafloor sediments (fig. 2). This paper reviews what is known about these naturally occurring gas hydrates.

\section{GAS HYDRATES IN PERMAFROST REGIONS}

The fact that temperature and pressure conditions beneath permafrost regions fall within the stability field of gas hydrates (fig. 3) was recognized in the $1940^{\prime} \mathrm{s}$. Now several deposits of gas hydrate are known (table 1). In 1970, we11 logging and formation tests in the rossoyakha gas field in western Siberia revealed billions of cubic meters of methane gas frozen as gas hydrate (Makogon and others, 1971, 1972; both

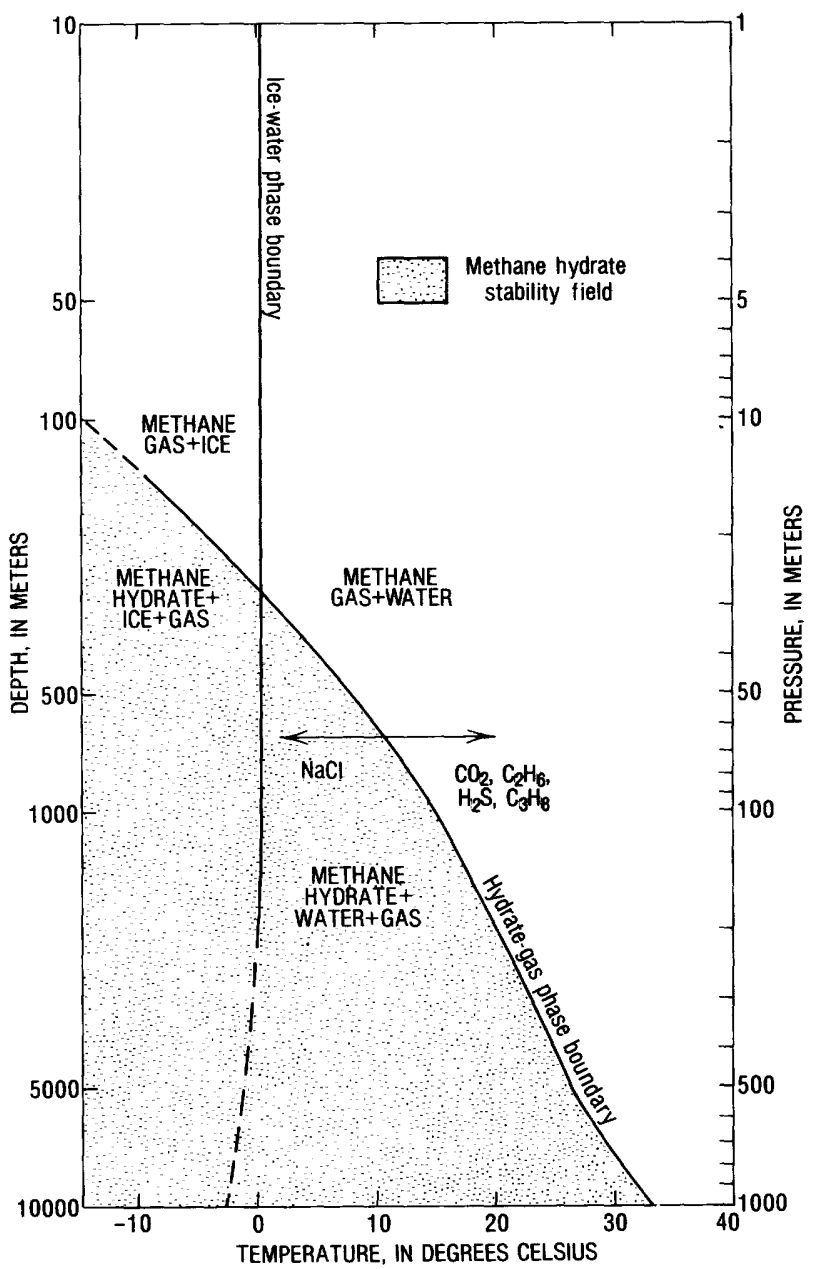

Figure 1--Phase boundary diagram showing: free methane gas and methane hydrate (pattern) for a fresh water-pure methane system. Addition of $\mathrm{NaCl}$ to water lowers temperature of hydrate formation, in effect shifting gas-hycrate curve to left. Addition of $\mathrm{CO}_{2}, \mathrm{H}_{2} \mathrm{~S}, \mathrm{C}_{2} \mathrm{H}_{6}$, or $\mathrm{C}_{3} \mathrm{H}_{8}$ raises temperature of hydrate formation, in effect shifting curve to right. Therefore, impurities in natural gas will increase area of hydrate stability field. Depth scale is an approximation assuming that lithostatic and hydrostatic pressure gradients are both 0.1 atmosphere per meter $(10.1 \mathrm{kPa} / \mathrm{m})$, but the true lithostatic gradient is slightly greater. Redrawn after Katz and others (1959). 


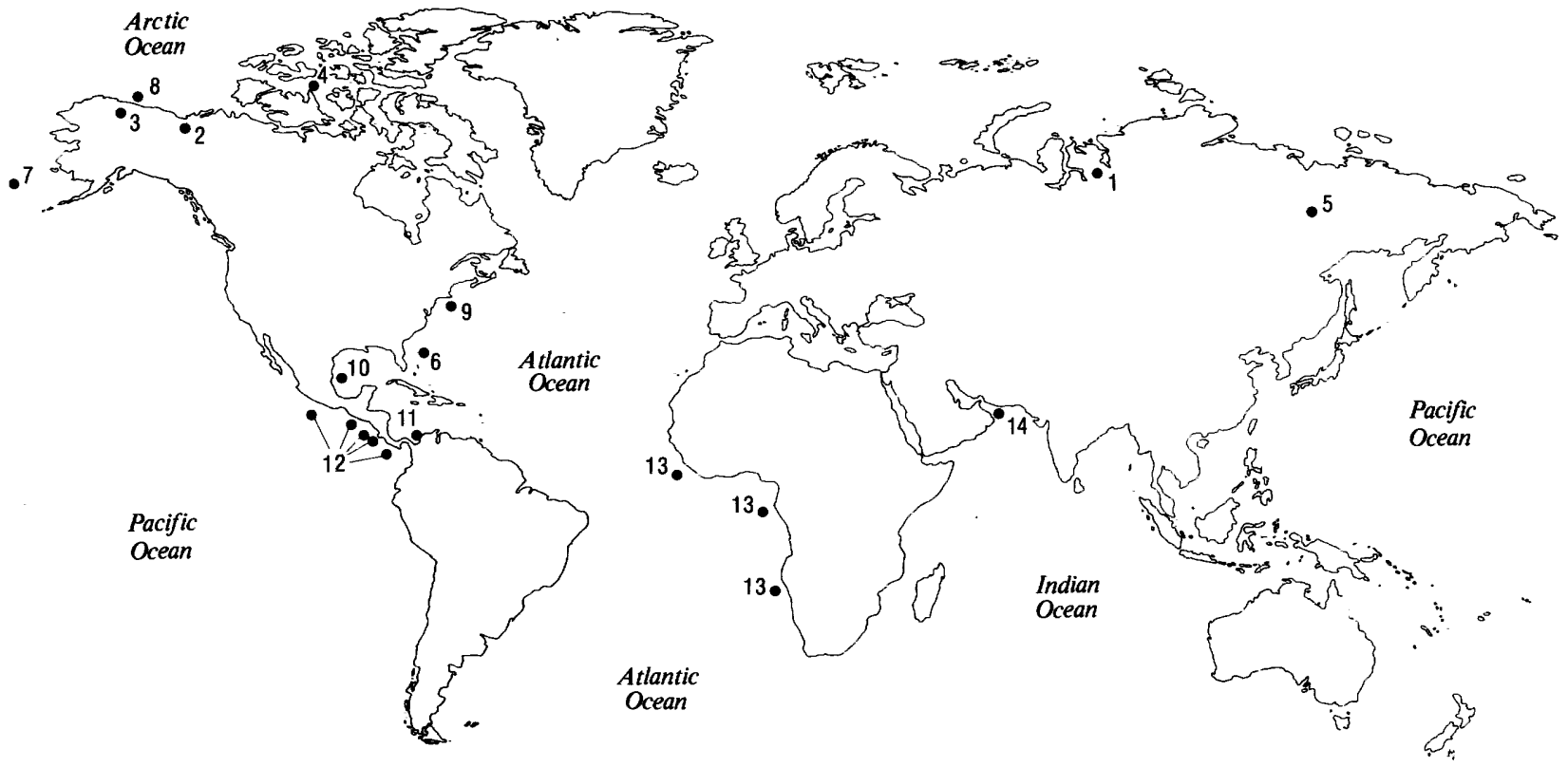

Figure 2.--Known and inferred accumulations of gas hydrate. Dots on 1and depict suspacted or confirmed occurrences of gas hydrates beneath permafrost. Dots in oceans show areas where seismic or drilling evidence suggests presence of gas hydrates. See tables 1 and 2 for a 1 isting of each site, along with geologic, geophysical, and geochemical evidence for hydrate presence, research organization involved, and pertinent references.

references cited by Milton, 1976). Methane was released from the gas hydrate by injecting methanol into test wells that perforated the hydrate zone. The injections of methanol, which serves as a hydrate inhibitor, resulted in a large increase in gas productivity from the test wells. The parts of the Messoyakha field containing gas hydrates are calculated to have 54 percent more reserves than would be expected in an equal volume of reservoir rocks filled with free gas.

Two exploratory wells drilled in permafrost of the Mackenzie Delta penetrated shallow sand reservoirs containing gas hydrate at depths of 820 to $1,100 \mathrm{~m}$ (Bily and Dick, 1974). The amount of formation gas in the drilling mud increased significantly during penetration of these sands. Although these sands were very porous, their permeability was extremely low. Low permeability and pronounced gas release are characteristic of hydrate-filled reservoirs. The lor permeability is thought to result from the plugging of sediment interstices by gas hydrate, and the gas 1iberated is attributed to hydrate decomposition. other characteristics of the gas hydrate zone are visible on well logs (Bily and Dick, 1974). The hydrate-bearing sands lave a relatively high resistivity. Spontanecus potential (SP) curves show very little deflection in hydrate zones in comparison with deflections in free-gas and free-water zones. Soric logs show

Table 1.--Evidence for gas hydrates beneath permafrost

\begin{tabular}{|c|c|c|c|c|c|c|c|}
\hline $\begin{array}{l}\text { Num- } \\
\text { ber } \\
\text { on } \\
\text { fig. } \\
2\end{array}$ & Location & $\begin{array}{l}\text { Permafrost } \\
\text { thickness } \\
\quad(m)\end{array}$ & $\begin{array}{l}\text { Predicted } \\
\text { depth range } \\
\text { of hydrate } \\
(\mathrm{m})\end{array}$ & $\begin{array}{l}\text { Geophysical } \\
\text { evidence }\end{array}$ & $\begin{array}{l}\text { Geochemical } \\
\text { evidence }\end{array}$ & $\begin{array}{l}\text { Research } \\
\text { organization }\end{array}$ & References \\
\hline 1 & $\begin{array}{l}\text { Messoyakha gas field and } \\
\text { northwestern Siberia, } \\
\text { U.S.S.R. }\end{array}$ & $450 \cdots$ & $--250-870-\cdots$ & 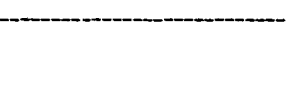 & $\begin{array}{l}90 \text { pct. or more meth- } \\
\text { ane in gas analysis; } \\
\text { large vol une of gas } \\
\text { from thawed cores. }\end{array}$ & -U.S.S.R.- - & $\begin{array}{l}\text { Makogon and } \\
\text { others, } 1971 .\end{array}$ \\
\hline 2 & $\begin{array}{l}\text { Mackenzie Delta, Northwest } \\
\text { Territories, Canada }\end{array}$ & $610-\cdots$ & $--820-1100-\cdots$ & $\begin{array}{l}\text { Well logs: small deflection } \\
\text { in SP; high resistivity; } \\
\text { h1gh velocity sonic log; } \\
\text { over-gage caliper log. }\end{array}$ & - do.- & $\begin{array}{l}\text { Imperial oil, } \\
\text { Ltd. }\end{array}$ & $\begin{array}{l}\text { B11y and Dick, } \\
1974 \text {. }\end{array}$ \\
\hline 3 & $\begin{array}{l}\text { West Prudhoe Bay, Alaska, } \\
\text { U.S.A. }\end{array}$ & 610---- & $--210-1100-$ & $\begin{array}{l}\text { We11 logs: high resistivi- } \\
\text { t1es; high velocity sonic } \\
\text { log; gas kicks in mud logs. }\end{array}$ & 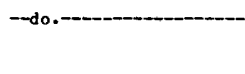 & - Exxon-- & $\begin{array}{l}\text { R. D. Mc Iver, } \\
\text { wrttten commun., } \\
1979 \text {. }\end{array}$ \\
\hline 4 & $\begin{array}{l}\text { Arctic Archipelago, North- } \\
\text { west Territories, Canada }\end{array}$ & $530-\cdots$ & $\begin{array}{l}\text { No data } \\
\text { in print. }\end{array}$ & - & -No data in print-- & $\begin{array}{l}\text { Done Petroleum, } \\
\text { Ltd. }\end{array}$ & Hitchson, 1974. \\
\hline 5 & $\begin{array}{l}\text { Vil yuy Basin, Yakutia, } \\
\text { U.S.S.R. }\end{array}$ & $>500=$ & -- do. & 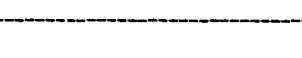 & 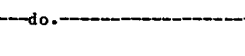 & --U.S.S.R.-_-_- & $\begin{array}{l}\text { Makogon and } \\
\text { others, } 1972 .\end{array}$ \\
\hline
\end{tabular}


an increase in acoustic velocity, and the caliper log indicates over-gage borehole through many hydrate-bearing zones.

The first conclusive confirmation that gas hydrates occur in sediments under permafrost was obtained from pressure core barrel samples at the Arco-Exxon N.W. Eileen State No. 2 wildcat we1l on the north slope of Alaska in the West Prudhoe Bay field (R.D. McIver, written commun., 1979). Two pressurized cores were successfully recovered and were maintained in the barrel at temperatures slightly above $0^{\circ} \mathrm{C}$. At the time the cores were collected it was uncertain whether the cores had contained gas hydrate or only pressurized free methane. If the cores had contained free gas at in situ temperature and pressure, the pressure in

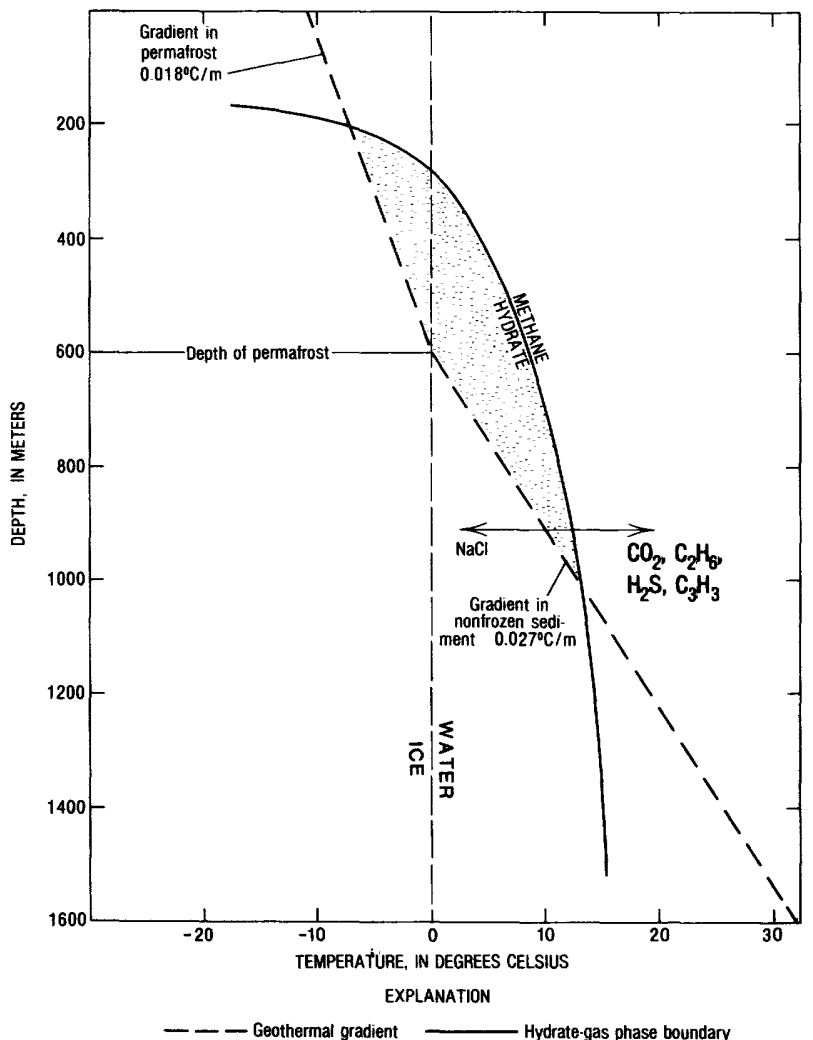

Gas hydrate zone

Figure 3.--Gas hydrate zone, shown as area between intersections of geothermal gradient with hydrate-gas phase boundary curve. Within this area, pressure and temperature conditions are favorable for hydrate formation. Plot shows pure methane hydrate zone for an Arctic region in which permafrost is $600 \mathrm{~m}$ thick and enough methane is present to form hydrate. Pressure gradient is $0.1 \mathrm{~atm} / \mathrm{m}(10.1 \mathrm{kPa} / \mathrm{m})$. Geothermal gradient changes at base of permafrost. Changes in gas composition or water salinity will shift phase boundary curve in same sense as figure 1. Redrawn after Bily and Dick (1974). the barrel would have been expected to decrease linearly as gas was withdrawn from tho barrel. However, pressure was maintained even after repeated samples were withdrawn. This result could only have been caused by the decomposition of hydrate after each increment of pressure release and gas removal. Immediately after $\epsilon$ ach sample was removed and the system closed, pressure began to build toward the pressure of hydrote equilibrium. The sampled gas was 93 percent methane and 7 percent nitrogen.

We11 logs in the Eileen well also indicated the hydrate zone. Whereas strong muci-gas shows suggested free gas in the formation, the high resistivities and high velocities on the sonic $\log$ indicated ice or icelike materials. The density $\log$ also responded as if there were ice rather than gas in the formation. Ir combination the resistivity, sonic, and mud logs pointed to the presence of hydrates.

In addition to the North Slope, the Mackenzie Delta, and the western Siberian $\mathrm{k}$ asin, the Arctic Archipelago of Canada and the Vilyuy basin of the U.S.S.R. show evidence of gas hydrate deposits. Gas-flow data from a well in Winter Harbor in the Arctic Archipelago suggested the presence of gas hydrates (Hitchon, 1 n74). Makogon and others (1972) reported that the Central Vilyuy gas field in Yakutia, U.S.S.R., contains gas hydrates beneath permafrost.

Any sedimentary basin with extersive areas of relatively thick (several hundred meters) continuous permafrost may contain potentially commercial occurrences of gas hydrates. Antarctica may have large gas hydrate accumulations, a1though few data on Antarctic permafrost areas are available (Hitchon, 1974). No drilling program has been conducted on the Antarctic continent except for a few experimental holes, but the land temperature profile is such that gas hydrates could exist at depths of,more than $1,800 \mathrm{~m}$.

\section{GAS HYDRATES IN OCEANIC SEDIMENTS}

Pressure and temperature conditions in the deep sea floor are within the range of gas hydrate stability (fig. 4), and the possible presence of gas hydrates has been noted in several areas (table 2). Observation of deep-sea sediment cores that release large quantities of methane suggest that gas hydrates exist in some areas beneath the seafloor. In reviews of sediment gas data from the Deep Sea Drilling Project (DSDP), Claypool and others (1973; Legs 10-19) and Mc Iver (1974; Legs 18-23) described instances where gas evolved from core samples after they were taken on deck. Gas evolution sometimes continued for several hours, and the pressures generated were occasionally sufficient to extrude cores from the barrel and rupture sealed containers. The expanding, cooling gas forned ice on the exposed cores. The quantity and rate of gas evolution could indicate the decomposition of gas hydrate, although high concentrations of gas not in hydrated form can produce similar results. In most instances, the gas was methane with traces 
of ethane. Recent results from DSDP Legs 66 and 67 provide more evidence for the presence of gas hydrates in sediments on the slope of the MidAmerica Trench off Central America (Geotimes, 1979a, 1979b). On both of these legs, gas-releasing cores were observed. Frozen sediment was recovered from the zone of hydrate stability at Sites 490, 491, 492, 497, and 498. Gas expansion volumes as high as 50 to 1 ( $R$. von Huene, oral commun., 1979) suggest that gas hydrates had indeed been sampled.

Methane in ocean sediment may be of either biochemical or thermal origin. It is uncertain, however, that enough gas to support the formation of gas hydrate can be generated by methane-producing bacteria alone. Claypool and Kaplan (1974) estimated that biological generation of methane in sediment containing 0.5 percent organic carbon near sediment depths of around 1,000 m (corresponding to $30^{\circ} \mathrm{C}$ ) is $20 \mathrm{mmol}$ per kilogram of interstitial water. They also estimated the threshold methane concentration for hydrate stability as $58 \mathrm{mmol} / \mathrm{kg}$. Thermocatalytic methane is produced by alteration of organic matter at temperatures greater than $50^{\circ} \mathrm{C}$, but gas hydrates are stable only at relatively low temperatures. For gas hydrates to form from thermocatalytic natural gas (methane), such gas must migrate upward from burial depths greater than $1,500 \mathrm{~m}$ into cooler regions where it could be incorporated into a gas hydrate zone.

\section{BOTTOM-SIMULATING REFLECTORS}

A bottom-simulating reflector is an anoma1ous seismic reflector that parallels the topography of the seafloor but lies anywhere from 100 to $1,100 \mathrm{~m}$ below the bottom. Bottom-simulating reflectors are most easily recognized on seismic records when they cut across other reflectors and occur in water depths greater than $400 \mathrm{~m}$. They

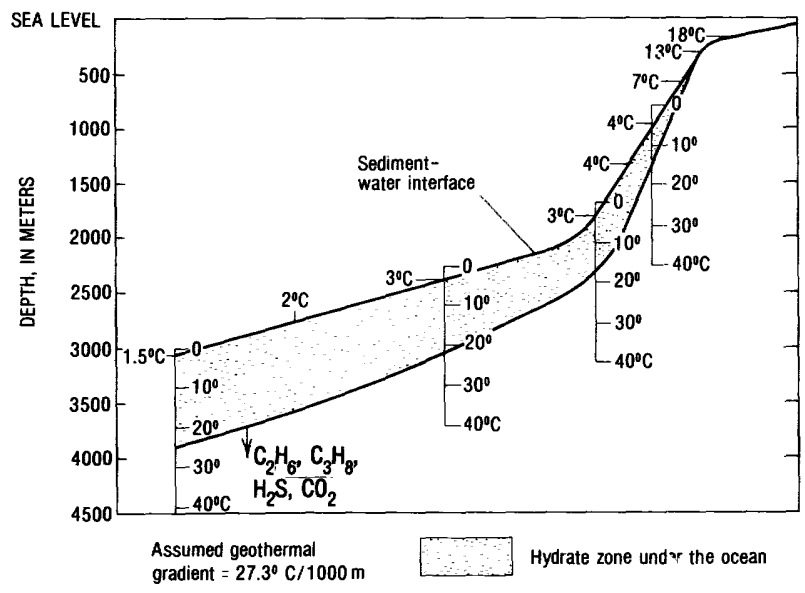

Figure 4.--Idealized section of gas hydrate zone in sediments of outer continental mar?ins, computed for pure methane. Stippled zone is potential area of hydrate formation, where pressure and temperature conditions are correct for hydrate stability assuming an adequate supply of methane. Presence of other gases in methane would increase methane hydrate envelope downward. Increasing pressure from height of water column causes increase in subbottom depth of gas hydrate zone. Decreasing sediment temperature (down to $1^{\circ} \mathrm{C}$ in coldest, deepest bottom waters) also decreases hydrate subbottom depth. Redrawn fron R.D. McIver, written commun., 1979.

Table 2.--Evidence for gas hydrates in the seafloor

\begin{tabular}{|c|c|c|c|c|c|c|c|c|}
\hline $\begin{array}{l}\text { Num- } \\
\text { ber } \\
\text { on } \\
\text { fig. } \\
2 \\
\end{array}$ & Location & $\begin{array}{l}\text { Water } \\
\text { depth } \\
\text { (ख) }\end{array}$ & $\begin{array}{l}\text { Predicted sub- } \\
\text { bottom depth } \\
\text { range of } \\
\text { hydrate } \\
\text { (m) }\end{array}$ & $\begin{array}{l}\text { Bottom- } \\
\text { simulating } \\
\text { reflectors } \\
\text { (subbottom } \\
\text { depth, m) }\end{array}$ & $\begin{array}{l}\text { Other } \\
\text { geophysical } \\
\text { evidence }\end{array}$ & $\begin{array}{l}\text { Geochemical } \\
\text { evidence }\end{array}$ & $\begin{array}{c}\text { Research } \\
\text { organization }\end{array}$ & Refer snces \\
\hline 6 & $\begin{array}{l}\text { Blake-Bahama Outer Ridge, } \\
\text { western Atlantic, off } \\
\text { east coast of U.S.A. }\end{array}$ & 3700 & $0-1000 \cdots$ & -about 500 & $-\infty+\infty-\infty$ & $\begin{array}{l}90 \text { pct. or more methane } \\
\text { in gas analysis; large } \\
\text { vol ume of gas from } \\
\text { thawed cores. }\end{array}$ & $\begin{array}{l}\text { Lamont-Doherty, } \\
\text { DSDP, and USGS. }\end{array}$ & $\begin{array}{l}\text { Mark1 and others, } \\
1970 \text {; Ewing and } \\
\text { Hollister, 1972; } \\
\text { Dillon and others, } \\
1980 \text {. }\end{array}$ \\
\hline 7 & Bering Sea, North Pacific & $\begin{array}{l}2000- \\
4000+\end{array}$ & $0->1000 \cdots$ & $-580-670 \cdots$ & $\begin{array}{l}\text { VAMP's, }>500 \mathrm{~m} \\
\text { beneath the } \\
\text { seafloor. }\end{array}$ & $\begin{array}{l}90 \text { pct. or more methane } \\
\text { in gas analysis. }\end{array}$ & --DSDP and USCS---- & $\begin{array}{l}\text { Scholl ard Creager, } \\
\text { 1973; Scholl and } \\
\text { Cooper, } 1978 \text {. }\end{array}$ \\
\hline 8 & Beaufort Sea, Arctic Ocean & $\begin{array}{l}400- \\
2500+\end{array}$ & $0-700+\cdots$ & $--100-300--$ & 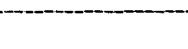 & -No data in print-- & --OUSGS----O--_--- & $\begin{array}{l}\text { Grantz ard others, } \\
1976 \text {. }\end{array}$ \\
\hline 9 & Western North Atlantic & $\begin{array}{l}2500- \\
3800\end{array}$ & $0 \rightarrow 1000-\ldots$ & $---500-600-\cdots$ & 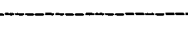 & do._- & ---Lamont-Doherty--- & $\begin{array}{l}\text { Tucholke and } \\
\text { others, } 1977 .\end{array}$ \\
\hline 10 & Western Gulf of Mexico & $\begin{array}{l}1200- \\
2000\end{array}$ & $0-500 \cdots$ & $--100-1100--$ & (1) & 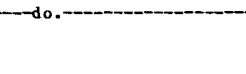 & $\begin{array}{l}\text { Mniv. of Texas, } \\
\text { Marine Science } \\
\text { Institute. }\end{array}$ & $\begin{array}{l}\text { Shipley and others, } \\
1979 \text {. }\end{array}$ \\
\hline 11 & $\begin{array}{l}\text { Northern Colombian and nor- } \\
\text { thern Panamanian coasts }\end{array}$ & $\begin{array}{l}1500- \\
3000\end{array}$ & $0-800-\cdots$ & $-100-1100--$ & (-1) & 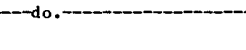 & 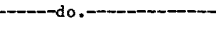 & - - Do. \\
\hline 12 & $\begin{array}{l}\text { Central America, Pacific } \\
\text { side }\end{array}$ & $\begin{array}{l}800- \\
2400\end{array}$ & $0-650-$ & $--100-1100-$ & - & --do.-- & - & -Do. \\
\hline 13 & Western Africa & $\begin{array}{l}2000- \\
5500\end{array}$ & $0 \rightarrow 1000-\cdots$ & $-\infty-\infty+\infty-\infty$ & $\begin{array}{l}\text { Pagoda structures } \\
\text { at very shallow } \\
\text { depth. }\end{array}$ & --do.- & -Woods Hole, Mass. & Emery, 1974 . \\
\hline 14 & Gulf of Oman & 3000 & $0-800-\cdots$ & 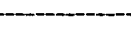 & $\begin{array}{l}\text { Bright spots at } \\
600-700 \text { an depth. }\end{array}$ & - do.- & -Cambridge, U.K. & White, 1979. \\
\hline
\end{tabular}


are generally characterized by reflection polarity reversals and large reflection coefficients (Shipley and others, 1979). Gas hydrate zones and diagenetic boundaries in sediment have been proposed as possible causes of these anomalous seismic reflectors.

Before DSDP Leg 11 in the Blake-Bahama region of the Atlantic Ocean, geophysicists of the Lamont-Doherty Geological Observatory were intrigued by bottom-simulating reflectors on their seismic records over the Blake-Bahama Outer Ridge (Markl and others, 1970; Stoll and others, 1971). The observation that some of the seismic reflectors on their records intersected other reflectors and paralleled the seafloor (fig. 5) was unexplained. One of the major objectives of Leg 11 was to investigate the nature of the bottom-simulating reflectors and determine their relation, if any, to accumulations of gas hydrate beneath the seafloor. The strongest reflector on the ridge mimicked the ridge profile at a depth of more than $500 \mathrm{~m}$ below the seafloor. Samples from Sites 102, 103, and 104 of Leg 11 yielded mainly methane and traces of ethane (for quantitative gas composition data see Claypool and others, 1973). The strong bottom-simulating reflector was at that time correlated with a distinct break in the drilling rate and with a zone of nodules of siderite and ankerite (Lancelot and Ewing, 1972). Another explanation, suggested by Stol1, Ewing, and Bryan (1971), Ewing and Hollister (1972), and Dillon, Grow, and Paull (1980), is that the bottom-simulating reflector corresponds to the isotherm that separates a gas environment from a gas hydrate environment. The average thermal gradient for the ridge (about 35$40^{\circ} \mathrm{C} / \mathrm{km}$ ) permits a gas hydrate to exist at the 500-m sediment depth of the strong reflector, but below that level the temperature would be high

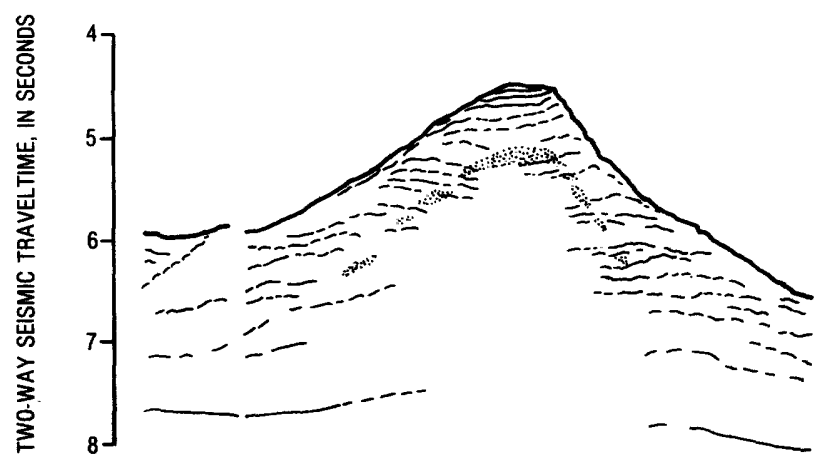

\begin{tabular}{l}
50 \\
\hline
\end{tabular}

Figure 5.--Diagrammatic seismic profile of BlakeBahama Outer Ridge, showing thin, regularly spaced reflectors from strata. Bottom-simulating reflector (stippled) transects bedding and parallels seafloor and may represent hydrate-to-free-gas transition at bottom of gas hydrate zone. Redrawn from Tucholke and others (1977). enough that methane could exist only as a gas. The interface between gas hydrate above and free gas below could provide a velocity contrast that is responsible for the bottom-simulating reflector. Furthermore, the apparent acoustic velocity through sediment overlying this reflector was determined to be about $2 \mathrm{~km} / \mathrm{s}$ (Lancelot and $\mathrm{Ew}-$ ing, 1972). This value, later confirmed by independent sonobuoy measurements (Bryan, 1974), is unusually high for hemipelagic setiment.

Laboratory experimental studies provide further evidence linking gas hydrates with the sediments of the Blake-Bahama Ridge. Sto11, Ewing, and Bryan (1971) demonstrated that when methane mixed with water-saturated sand was brought to the estimated temperatures and pressures of the Blake-Bahama Ridge sediment, the velocity of compressional seismic waves in the sand increased from 1.7 to $2.5 \mathrm{~km} / \mathrm{s}$. This experimental increase in seismic velocity helps explain the unusually high velocities observed in hemipolagic sediment of the ridge.

Since they were first found in the BlakeBahama Ridge (Mark1 and others, 1970; Ewing and Ho11ister, 1972), other bottom-simulating reflectors have been reported (fig. 3) from the western North Atlantic Ocean (Tucholke and others, 1977), the Beaufort Sea of the Arctic Ocean (Grantz and others, 1976), and the Bering Sec and elsewhere in the North Pacific Ocean (Scholl and Creager, 1973). Shipley and others (1979) described bottom-simulating reflectors in sediments off the east coast of the United States, in the western Gulf of Mexico, off the northern coasts of Colombia and Panama, and along the Pacific coast of Central America from Panama to Acapulco, Mexico. From studies of the western North Atlantic, Tucholke, Bryan, and Ewing (1977) identified two high-amplitude reflecting horizons that are conformable with the seafloor and at out 500 to $600 \mathrm{~m}$ beneath it. These horizons show the following characteristics: they cut across bedding-plane reflectors in the same manner as the reflector horizon observed on the Blake-Balama Ridge; they appear to be restricted to areas where sedimentary strata dip landward; and their subbottom depth increases with the seafloor depth, a relation consistent with theoretical predictions of the configuration of a hydrate zone (fig. 4). A zone of gas hydrates may overlie the anomalous horizons, and thus the seismic horizons could be reflectors representing an impedance contrast caused by the downward change from gas hydrate to gas in the sediment. Grantz and others (1976) identified a strong seismic reflector that mimics the bathymetry of the seafloor, 100-300 m beneath $i t$, on the continental slope of the Beaufort Sea north of Alaska. The bottom-simulating reflector was identified in about 60 percent of seismic profiles obtained in water deeper than 400-600 m. Not all bottom-simulating reflectors can be directly related to the presence of gas hydrates. Although gas hydrates provide one reasonable explanation for bottom-simulating reflectors, these acoustic features may also result from temperature controlled diagenetic effects. Dur- 
ing DSDP Leg 19, Scholl and Creager (1973) noted seismic reflectors that tend to parallel the seafloor in some Bering Sea sediments draped on the Unnak Plateau, and they coined the acronym BSR for the bottom-simulating reflector. At two sites, 184 and 185 , the reflector was penetrated. Although methane was observed in sediment from Site 185, no other evidence for gas hydrates was noted. Scholl and Creager (1973) attribute this reflector to a 1ithologic transition from hemipelagic diatom ooze to indurated claystone. Because of the time-transgressive nature of this horizon, this BSR appears to represent some sort of migratory diagenetic boundary related to the dissolution of diatoms and the formation of claystone. Hein and others (1978) confirmed that opa1-A is transformed to opal-CT in the temperature range corresponding to a subbottom depth of $600 \mathrm{~m}$, the depth of the BSR in Bering Sea sediment. Further, because the subbottom depth of the BSR on the flanks of Umnak Plateau decreases with increasing water depth, this BSR is probably not directly caused by gas hydrates (Shipley and others, 1979). Nevertheless, gas hydrates may still play an important role in the formation of this BSR. Claypool and Kaplan (1974) note that, in all cases of BSR's described from the Bering Sea, the lithologic change is consistent with the inferred depth of the isotherm where gas hydrate would decompose under the prevailing pressure conditions. Claypool and Kaplan (1974) suggest at least an indirect link between lithification and gas hydrate. Free carbon dioxide and methane concentrations determine the $\mathrm{pH}$ of interstitial water. The $\mathrm{pH}$ conditions determine the solubility of 1ithologic components such as carbonate and silica. Gas hydrate formation may influence carbon dioxide and methane activities and may therefore influence the dissolution and reprecipitation of carbonate and silica cements.

Thus, some bottom-simulating reflectors are not directly related to the presence of gas hydrates, as illustrated above, but bottom-simulating reflectors may not be observed even though gas hydrates are present. For example, in areas where sedimentary stratification parallels the seafloor, the bottom-simulating reflector may not be detectable. During drilling on DSDP Leg 67 in the Mid-America Trench off Guatemala, gas hydrates apparently were encountered at Sites 497 and 498, but the seismic records for these areas showed no obvious bottom-simulating reflectors (R. von Huene, oral commun., 1979).

Gas hydrate zones in the seafloor may form regionally extensive impermeable seals and may trap economically important accumulations of natural gas, provided sufficient sources for methane are present. If gas were to migrate upward and be impeded by hydrate, it would accumulate at the lower boundary of the hydrate zone as free gas and would cause a significant decrease in seismic velocity at that boundary (Bryan, 1974). Bottom-simulating reflectors are strongest in the vicinity of ridge crests and tend to fade out on the flanks (Mark1 and others, 1970), a configuration that suggests gas accumulation at the crest as in an anticlinal trap.

\section{OTHER SEISMIC EVIDENCE FOR GAS HYD'ATES IN OCEANIC SEDIMENTS}

Seismic features other than bottom-simulating reflectors may be produced by gas hydrates. These features include bottom-parallel bright spots, pagoda structures, and deep-water velocity amplitude features (VAMP's). White (1977) suggested that seismic bright spots (amplitude anomalies) in the Gulf of Oman are caused by natural gas accumulations. These subbottom reflectors are curved, mimic the topography of the seafloor, and transgress local bedding (making these bright spots similar to bottom-simulating reflectors, but of lesser lateral extent). White (1979) inferred that the gas is held in place not by a stratigraphic trap but by an impermeable gas hydrate layer that follows the seafloor topography.

Emery (1974) has suggested that pagoda structures may be related to gas hydrates, although these are very shallow subbottom seismic features, and there is little consensus regarding their significance. Geophysical traverses across nearly flat mud bottom at depths between 2,000 and $5,000 \mathrm{~m}$ off western Africa provided extensive seismic shallow-penetration recordings at 3.5 $\mathrm{kHz}$. The recordings reveal the presence of common alternating light and dark triangular seismic features, or pagoda structures, whose internal structure and acoustic properties may, according to Emery (1974), be due to local centers of gas hydrate induration.

Velocity-amplitude features (VAMP's) are acoustic anomalies showing narrow ( 1 to $2 \mathrm{~km}$ ) subsurface columns of concave reflection horizons called pulldowns, associated with gently arched, high-amplitude horizons higher in the section (Scholl and Cooper, 1978). These kinds of acoustic anomalies, common on seismic profiles collected in the Bering Sea, are typically seen in flat-1ying beds at subbottom depths greater than $500 \mathrm{~m}$ and in deep water around 4,000 m. VAMP's are essentially deep-seated "bright spots" underlain by reflection horizon pulldowns. Gas hydrates may be responsible for VAMP's by contibuting to the restriction of upward-migrating gas and fluids.

It is difficult to detect gas hydrates by purely chemical and selsmic means. Support for the indentification of gas hydrate in seafloor sediments will result when cores containing $1 \mathrm{y}-$ drates recovered at their subsea temperatures and pressures can be analyzed. A pressure core tarrel capable of this task has been designed by DSDP but has never been successfully deployed in a gas hydrate horizon. From the geologic, geophysical, and geochemical evidence obtained thus far, there is little doubt that gas hydrates are an important part of the marine sedimentary record. 


\section{SELECTED BIBLIOGRAPHY}

The following is a selected bibliography containing the references cited in this paper along with other papers dealing with the physical chemistry, geology, and geophysics of gas hydrates. This bibliography does not represent an exhaustive search of the literature, but rather includes those pertinent papers readily available to us.

Baker, P.E., 1974, Experiments on hydrocarbon gas hydrates in unconsolidated sand, in Kaplan, I.R., ed., Natural gases in marine sediments: New York, Plenum, p. 227-234.

Barnes, R.0., and Goldberg, E.D., 1976, Methane production and consumption in anoxic marine sediments: Geology, v. 4, p. 297-300.

Barnes, W.C., 1975, Some structural implications of gas hydrates in deep-ocean sediments: Geological Society of America Abstracts with Programs, v. 7, p. 989-999.

Barrer, R.M., and Stuart, W.I., 1957, Non-stoichiometric clathrate compounds of water: Proceedings of the Royal Society of London, Ser. A, v. 243, no. 1233, p. 172-189.

Bily, C., and Dick, J.W.L., 1974, Naturally occurring gas hydrates in the Mackenzie De1ta, N.W.T.: Bulletin of Canadian Petroleum Geology, v. 22, p. 320-352.

Brown, J.F., Jr., 1962, Inclusion compounds: Scientific American, v. 207, no. 1, p. 82-92.

Bryan, G. M., 1974, In situ indications of gas hydrates, in Kaplan, I.R., ed., Natural gases in marine sediments: New York, Plenum, p. 299-308.

Buffler, R.T., Shaub, F.J., Watkins, J.S., and Worze1, J.L., 1979, Anatomy of the Mexican ridges, southwestern Gulf of Mexico, in Watkins, J.S., Montadert, L., and Dickerson, P.W., eds., Geological and geophysical investigations of the continental margins: American Association of Petroleum Geologists Memoir No. 29 , p. 319-327.

Carson, D. B., and Katz, D.L., 1942, Natural gas hydrates: Petroleum Transactions of the American Institute of Mining Engineers, v. 146, p. $150-158$.

Chan, J.P., and Giauque, W.F., 1964, The entropy of $\mathrm{NH}_{3} \cdot 2 \mathrm{H}_{2} \mathrm{O}$ : Heat capacity from 15 to $300^{\circ} \mathrm{K}$ : Journal of Physical Chemistry, v. 68, p. 30533057.

Claussen, W.F., 1951a, Suggested structures of water in inert gas hydrates: Journal of Chemical Physics, v.19, p. 259-260. 1951b, Erratum: Suggested structures of water in inert gas hydrate: Journal of Chemical Physics, v. 19, p. 662 .

1951c, A second water structure for inert gas hydrates: Journal of Chemical Physics, $v$. 19 , p. 1425-1426.

Claypool, G. E., and Kaplan, I.R., 1974, The origin and distribution of methane in marine sediments, in Kaplan, I. R., ed., Natural gases in marine sediments: New York, Plenum, p. 99139.

C1 aypoo1, G.E., Presley, B.J., and Kaplan, I.R., 1973, Gas analysis in sediment samples from Legs $10,11,13,14,15,18$, and 19, in Creager, J.S., Scholl, D.W., and others, Initial reports of the Deep Sea Drilling Project, v. 19: U.S. Government Printing office, p. 879884 .

Cooper, A.K., Scholl, D.W., Marlow, M.S., Childs, J.R., Redden, G.D., Kvenvolden, K.A., and Stevenson, A.J., 1979, Hyd rocarbon prtential of the Aleutian Basin, Bering Sea: Anerican Association of Petroleum Geologists Bulletin, v. 63, p. 2070-2087.

Creager, J.S., Scholl, D.W., and Supko, P.R., 1973, Introduction, in Creager, J.S., Schol1, D.W., and others, Initial reports of the Deep Sea Drilling Project, v. 19: U.S. Government Printing office, p. 3-16.

Culbertson, 0.L., and McKetta, J.J., Jr., 1951, Phase equilibria in hydrocarbon-water systems III--the solubility of methane in water at pressures to 10,000 psia: Petroleum Transactions of the American Institute of Mining Engineers, v. 192, p. 23-226.

Davidson, D.W., 1971, The motion of guest molecules in clathrate hydrates: Canadian Journal of Chemistry, v. 42, p. 1224-1242.

1973, Clathrate hydrates, in Franks, Felix, ed., Water: A comprehensive treatise, v. 2: New York, P1enum, p. 115-2ミ4.

Davidson, D.W., E1-Defrawy, M.K., Fuglem, M.0., and Judge, A.S., 1978, Natural gés hydrates in northern Canada: International Conference on Permafrost, 3d, Proceedings, v. 1, p. 937943.

Deaton, W.M., and Frost, E.M., Jr., 1948, Gas hydrates and their relation to the operation of natural-gas pipe lines: U.S. Bureau of Mines Monograph No. 8, $101 \mathrm{p}$.

Dillon, W.P., Grow, J.A., and Paul1, C.K., 1980 , Unconventional gas hydrate seals may trap gas off southeast U.S.: $0 i 1$ and Gas Journal, v. 78 , no. 1, p. 124-130. 
Emery, K.0., 1974, Pagoda structures in marine sediments, in Kaplan, I.R., ed., Natural gases in marine sediments: New York, Plenum, p. 309-317.

Emery, K.0., and Hoggan, D., 1958, Gases in marine sediments: American Association of Petroleum Geologists Bulletin, v. 42, p. 2174-2188.

Enns, T., Scholander, P.F., and Bradstreet, E.D., 1965, Effect of hydrostatic pressure on gases dissolved in water: Journal of Physical Chemistry, v. 69, p. 389-391.

Evrenos, A.I., Heathman, J., and Ralstin, J., 1971, Impermeation of porous media by forming hydrates in situ: Journal of Petroleum Technology, v. 23, p. 1059-1066.

Ewing, J.I., Ewing, Maurice, and Leyden, R., 1966, Seismic-profiler survey of the Bl ake Plateau: American Association of Petroleum Geologists Bulletin, v. 50, p. 1948-1971.

Ewing, J.I., and Hollister, C.H., 1972, Regional aspects of deep sea drilling in the western North Atlantic, in Hollister, C.H., Ewing, J.I., and others, Initial reports of the Deep Sea Drilling Project, v. 11: U.S. Government Printing office, p. 951-973.

Frost, E.M., Jr., and Deaton, W.M., 1946, Gas hydrate composition and equilibrium data: $0 i 1$ and Gas Journal, v. 45, no. 12, p. 170-178.

Garg, S.K., and Davidson, D.W., 1973, N.M.R. properties of clathrate ice, in Whalley, E., Jones, S.J., and Gold, L.W., eds., Physics and chemistry of ice: Ottawa, Royal Society of Canada, p. 56-60.

Gas Supply Committee, 1979, Gas from natural gas hydrates: Gas energy review, American Gas Association, v. 7, no. 10, p. 1-5.

Geotimes, 1979a, Middle American Trench: v. 24 , no. 9, p. 20-22.

Geotimes, 1979b, The Caribbean connection, v. 24, no. 12, p. 18-19.

Glew, D.N., 1962, Aqueous solubility and the gas-hydrates; The methane-water system: Journal of Physical Chemistry, v. 66, p. 605609.

Gold, L.W., and Lachenbruch, A.H., 1973, Thermal conditions in permafrost--A review of North American 1iterature, in Permafrost--The North American contribution, 2nd International Conference: Washington, National Academy of Sciences, $p$. 3-23.
Goldberg, Paul, 1963, Free radicals and reactive molecules in clathrate cavities: Science, $v$. 142 , p. 378-379.

Grantz, Arthur, Boucher, G.W., and Whitney, 0.T., 1976, Possible solid gas hydrate and natura1 gas deposits beneath the continental slope of the Beaufort Sea: U.S. Geological Survey Circular 733, p. 17.

Hagan, M.M., 1962, Clathrate inclusion compounds: New York, Van Nostrand-Reinhold, 189 p.

Hampton, Loyd, ed., 1974, Physics of sound in marine sediments: New York, Plenum, 567 p.

Hand, J.H., Katz, D.L., and Verma, V.K., 1974, Review of gas hydrates with implication for ocean sediments, in Kaplan, I.R., ed., Natural gases in marine sediments: New York, Plenum, p. 179-194.

Hedberg, H.D., 1974, Relation of methane generation to undercompacted shales, shale diapirs, and mud volcanoes: American Association of Petroleum Geologists Bulletin, v. 58, p. 661673.

Hein, J.R., Schol1, D.W., Barron, J.A., Jones, M.G., and Miller, J., 1978, Diagenesis of late Cenozoic diatomaceous deposits and fornation of the bottom simulating reflector in the southern Bering Sea: Sedimentology, v. 25, p. 155-181.

Hitchon, B., 1974, Occurrence of natural gas hydrates in sedimentary basins, in Kaplan, I.R., ed., Natural gases in marine sediments: New York, Plenum, p. 195-225.

Hodgson, Bryan, 1978, Natural gas: The search goes on: National Geographic Magazine, v. 154 , p. 632-651.

Holder, G.G., Katz, D.L., and Hand, J.H., 1976, Hydrate formation in subsurface envirorments: American Association of Petroleum Geologists Bulletin, v. 60, p. 981-984.

Hollister, C.D., Ewing, J.I., and others, 1972, Sites 102-103-104--B1ake-Bahama Outer Fidge (northern end), in Hollister, C.D., Ewing, J.I., and others, Initial reports of the Deep Sea Drilling Project, v. 11: U.S. Government Printing office, p. 135-143.

Howitt, Frank, 1971, Permafrost geology at Prudhoe Bay: World Petroleum, v. 42, no. $\varepsilon$, p. 28-32 and 37-38.

Hunt, J.M., 1979, Methane hydrates, in Hunt, J.M., Petroleum geochemistry and geology: San Francisco, W.H. Freeman, p. 156-162.

Jeffrey, G.A., 1969, Water structure in organic hydrates: Accounts of Chemical Research, v. 2 , p. 344-352. 
Jeffrey, G.A., 1972, Pentagonal dodecahedral water structure in crystalline hydrates: Material Research Bulletin, v. 7, p. 1259-1269.

Jeffrey, G.A., and McMul1in, R.K., 1967, The clathrate hydrates: Progress in Inorganic Chemistry, v. 8, p. 43-108.

Jhaveri, Jaysukh, and Robinson, D. B., 1965, Hydrates in the methane-nitrogen system: Canadian Journal of Chemical Engineering, v. 43, p. 75-78.

Judge, Alan, 1973, The prediction of permafrost thicknesses: Canadian Geotechnical Journal, v. $10, \mathrm{p} \cdot 1-11$.

Kaplan, I.R., ed., 1974, Natural gases in marine sediments: New York, Plenum, 324 p.

Katz, D.L., 1945, Prediction of conditions for hydrate formation in natura1 gases: Petroleum Transactions of the American Institute of Mining Engineers, v. 160, p. 140-149.

1971, Depths to which frozen gas fields (gas hydrates) may be expected: Journal of Petroleum Technology, v. 23, p. 419-423.

1972, Depths to which frozen gas fields may be expected--Footnotes: Journal of Petroleum Technology, v. 24, p. 557-558.

Katz, D.L., Cornell, D., Kobayashi, Riki, Poettmann, F.H., Vary, J.A., Elenblass, J.R., and Weinaug, C.F., 1959, Handbook of natural gas engineering: New York, McGraw-Hil1, 802 p.

Kobayashi, Riki, and Katz, D.L., 1949, Methane hydrate at high pressure: Petroleum Transactions of the American Institute of Mining Engineers, v. 186, P. 66-70.

Lancelot, Y., and Ewing, J.I., 1972, Correlation of natural gas zonation and carbonate diagenesis in Tertiary sediments from the north-west Atlantic, in Hollister, C.D., Ewing, J.I., and others, Initial reports of the Deep Sea Drilling Project, v. 11: U.S. Government Printing of fice, p. 791-799.

Langseth, M.G., Jr., and von Herzen, R.P., 1970, Heat flow through the floors of the oceans, in Maxwe11, A.E., ed., The sea, v. 4: New York, Wiley-Interscience, p. 299-352.

Makogon, Yu. F., Trebin, F.A., Trofimuk, A.A., Tsarev, V.P., and Cherskiy, N.V., 1971, Obnarvzheniye zalezhi prirodnogo gaza $v$ trerdom (gazogldratnom) sostoyanii ["Detection of a pool of natural gas in a solid (hydrated gas) state"]: Doklady Akademii Nauk SSSR, v. 196, p. 203-206 (in Russian); Doklady-Earth Science Section 196 (1972), p. 197-200 (in English).
Makogon, Yu. F., Trofimuk, A.A., Tsarev, V.P., and Cherskiy, N.V., 1973, Vozmozhnosti obrazovaniya gazogidratnykh zalezhey prirodnykh gazov $v$ pridonnoy zone morey $i$ okeanov ["Possible origin of natural gas hydrates at floors of seas and oceans"]: Akademiya Nauk SSSR Sibirskoye Otdeleniye Geologiya i Geofizika, no. 4, p. 3-6 (in Russian); International Geology Review, v. 16 (1974), p. 553-556 (in English).

Makogon, Yu. F., Tsarev, V.I., and Chersky, N.V., 1972, K voprosu formirovaniya krupnykh mestorozhdeniy gaza $\mathrm{v}$ zonakh pasprostraneniya ponizhennykh temperatur ["Formation of large natural gas fields in zones of permanently low temperatures"]: Doklady Akademii Nuk SSSR, v. 205, p. 700-703 (in Russian); Dok1 ady-Earth Science Section 205 (1973), p. 215-218 (in English).

Mandelcorn, Lyon, 1959, Clathrates: Chemical Reviews, v. 59, p. 827-839.

Mark1, R.G., Bryan, G.M., and Ewing, J.I., 1970, Structure of the Blake-Bahama Outer Ridge: Journal of Geophysical Research, v. 75, p. 4539-4555.

Marsha11, D.R., Saito, S., and Kobayashi, Riki, 1964, Hydrates at high pressure: I. Methane-water, argon-water, and nitrogen-water systems: American Institute of Cremical Engineers Journal, v. 10, p. 202-205.

Mc Iver, R.D., 1973, Hydrocarbons in canned muds from sites $185,186,189$, and $191-$-Leg 19 , in Creager, J.S., Scholl, D.W., and cthers, Initial reports of the Deep Sea Drilling Project, v. 19: U.S. Government Printing office, p. 875-877.

1974, Hydrocarbon gas (methane) in canned Deep Sea Drilling Project core samples, in Kaplan, I.R., ed., Natural gases in marine sediments: New York, Plenum, p. 63-69.

1977, Hydrates of natural gas--Important agent in geologic processes: Geological Society of America Abstracts with Prorrams, v. 9, p. 1089-1090.

Miller, S.L., 1974, The nature and occurrence of clathrate hydrates, in Kaplan, I.R., ed., Natural gases in marine sediments: New York, Plenum, p. 151-177.

Milton, D.J., 1976, Methane hydrate in the seafloor--A significant resource? in Meyer, $R$. F., ed., The future supply of nature-made petroleum and gas technical reports: New York, Pergamon, p. 927-943.

Noaker, L.J., and Katz, D.L., 1954, Gas hydrates of hydrogen sulfide-methane mixtures: Petroleum Transactions of the American Institute of Mining Engineers, v. 201, p. 237-239. 
Oil and Gas Journal, 1978, Soviets mull counting gas hydrates in fuel reserves: $0 i 1$ and Gas Journal, v. 76 , no. 43, p. 63 .

Parrish, W.R., and Prausnitz, J.M., 1972, Dissociation pressures of gas hydrates formed by gas mixtures: Industrial and Engineering Chemistry, Process Design and Development, v. 11 , p. 26-35.

Pena, Jorge, and de Pena, R.G., 1970, Freezing temperatures of water droplets $n$ equilibrium with different gases: Journal of Geophysical Research, v. 75, p. 2831-2835.

Pichon, Y.L., Ewing, J.I., and Houtz, R.E., 1968, Deep-sea sediment velocity determinations made while reflection profiling: Journal of Geophysical Research, v. 73, p. 2597-2614.

Ratcliffe, E.H., 1960, The thermal conductivities of ocean sediments: Journal of Geophysical Research, v. 65, p. 1535-1541.

Robinson, D.B., and Hutton, J.M., 1967, Hydrate formation in systems containing methane, hydrogen sulfide, and carbon dioxide: 'Journal of Canadian Petroleum Technology, v. 6, p. 69.

Savit, C.H., 1974, Bright spot in the energy picture: Ocean Industry, v. 9, no. 2, p. 6065.

Schol1, D.W., and Cooper, A.K., 1978, VAMPs-Possible hydrocarbon-bearing structures in Bering Sea basin: American Association of Petroleum Geologists Bulletin, v. 62, p. 24812488 .

Scho11, D.W., and Creager, J.S., 1973, Geologic synthesis of Leg 19 (DSDP) results: Far north Pacific, and Aleutian Ridge, and Bering Sea, in Creager, J.S., Scholl, D.W., and others, Initial reports of the Deep Sea Drilling Project, v. 19: U.S. Government Printing Office, p. 897-913.

Shipley, T.H., Buffler, R.T., and Watkins, J.S., 1978, Seismic stratigraphy and geologic history of the Blake Plateau and adjacent western Atlantic continental margin: American Association Petroleum Geologists Bulletin, v. 62, p. 792-812.

Shipley, T.H., Houston, M.H., Buffler, R.T., Shaub, F.J., McMillen, K.J., Ladd, J.W., and Worzel, J.L., 1979, Seismic reflection evidence for the widespread occurrence of possible gas-hydrate horizons on continental slopes and rises: American Association of Petroleum Geologists Bu1letin, v. 63, p. 22042213.
Sheriff, R.E., 1975, Factors affecting seismic amplitudes: Geophysical Prospecting, v. 23, p. 125-138.

Sto11, R.D., 1974a, Acoustic waves in saturated sediments, in Hampton, Loyd, ed., Physics of sound in marine sediments: New York, Plenum, p. 19-39.

,1974b, Effects of gas hydrates in sediments, in Kaplan, I.R., ed., Natural gases in marine sediments: New York, Plenum, p. 235248.

Sto11, R.D., and Bryan, G.M., 1979, Physical properties of sediments containing gas hydrates: Journal of Geophysical Resear $\mathrm{sh}, \mathrm{v}$. 84 , p. 1629-1634.

Stol1, R.D., Ewing, J.I., and Bryan, G.M., 1971, Anomalous wave velocities in sediments containing gas hydrates: Journal of Geophysical Research, v. 76, p. 2090-2094.

Takenouchi, S., and Kennedy, G.C., 1965, Di ssociation pressures of the phase $\mathrm{CO}_{2} \cdot 53 / 4$ $\mathrm{H}_{2} \mathrm{O}$ : Journal of Geology, v. 73, p. $383-390$.

Tucholke, B.E., Bryan, G.M., and Ewing, J.I., 1977, Gas-hydrate horizons detected in selsmic-profiler data from the western North At1antic: American Association of Petrol.eum Geologists Bulletin, v. 61, p. 698-707.

Trofimuk, A.A., Cherskiy, N.V., and Tsarev, V.P., 1973, Osobennosti nakopleniya prirodnykh gosov $v$ zonakh gidratoobrazovaniya Mirovcro okeana ["Accumulation of natural gases in zones of hydrate-formation in the hydrosphere"]: Doklady Akademii Nauk SSSR, v. 212, p. 931-934 (in Russian); Doklady-Earth Science Section 212 (1974), p. 87-90 (in English).

Unruh, C.H., and Katz, D.L., 1949, Gas hydrates of carbon dioxide-methane mixtures: Petroleum Transactions of the American Institute of Mining Engineers, v. 186, p. 83-86.

White, R.S., 1977, Seismic bright spots in the Gulf of Oman: Earth and Planetary Science Letters, v. 37, p. 29-37.

1979, Gas hydrate layers trapping free gas in the Gulf of Oman: Earth and Planetary Science Letters, v. 42, p. 114-120.

Yefremova, A.G., and Zhizhchenko, B.P., 1974, Obnaruzheniye kristal1-gidradov gazov v osadkakh sovremennykh akvatoriy ["Occurrence of crystal hydrates of gases in the sedimerts of modern marine basins"]: Doklady Akademii Nauk SSSR, v. 214, p. 1179-1181 (in Russian); Dok1ady-Earth Science Section 214 (1975), F. 219220 (in English). 
